\title{
A study on relationship between operating cash flows and performance evaluation criteria based on the theory of constraints (TOC) versus traditional method
}

\author{
Mohammad Sadegh Arabi Ashtiani*
}

M.Sc. of Accounting, School of Management, Tehran North Branch, Islamic Azad University (IAU), Tehran, Iran

\section{H R O N I C L E}

\section{Article history:}

Received May 8, 2013

Received in revised format

29 June 2013

Accepted 26 July 2013

Available online

July 272013

Keywords:

Theory of constraints

Tehran Stock Exchange

Operating cash flow

Performance measurement \begin{abstract}
A B S T R A C T
This study presents an empirical investigation to measure the relationship between traditional accounting performance measurement as well as theory of constraint-based figures with operating cash flow. Traditional accounting measurement includes net profit and return of investment and theory of constraint method includes net profit and return of investment based on theory of constraints. The study selects 69 firms list on Tehran Stock Exchange over the period 2000-2010. Using panel data and fixed effect, the study performs regression analysis and the results confirm that there was a positive relationship between net profit measured by theory of constraints and cash flow and it can be effectively used for performance measurement.
\end{abstract}

(C) 2013 Growing Science Ltd. All rights reserved.

\section{Introduction}

Measuring the performances of business units based on different financial figures plays an important role on the success of organizations (Said et al., 2008). Cash flow is one of the most important criteria for measuring the relative performance of organizations. Kaplan and Zingales (1997) investigated the relationship between financing constraints and investment-cash flow sensitivities. They reported that firms that appeared less financially constrained exhibit substantially bigger sensitivities than firms that appeared more financially constrained. Return of investment (ROI) is another important criterion for measuring the relative performance of business units (Carnevale \& Schulz, 1990). One of the primary concerns on measuring ROI traditionally is that it is sometimes difficult to calculate cost components, precisely. Theory of constraints (TOC) is another important criteria used for measuring the performance of firms. TOC uses a new criterion called throughput for measuring the performance of business units (Goldratt, 1990).

*Corresponding author. Tel: +98-912-3443139

E-mail address: ashtiani1366@gmail.com (M. S. Arabi Ashtiani) 
There are many applications of TOC on different areas of businesses such as performance measurement (Noreen et al., 1995; Campbell, 1995). Gupta et al. (1997), for instance, used TOC and activity based cost method (ABCM) in health care industry. Chakraborty et al. (2006) discussed on how to make managerial decision based on different existing constraints on the system. Lockamy III (2003) presented a constraint-based framework for strategic cost management.

Boyd et al. (2003) suggested different techniques for optimal decision making using cost accounting information. France (2010) discussed different issues in management accounting practices reflected in job advertisements. There are other similar studies on relationship between operating cash flow and earnings. For instance, Banimahd and Aliabadi (2013) investigated the effect of earnings management on operating cash flows management over the period 2004-2011 using the information of 119 firms listed on the Tehran Stock Exchange. They reported that there was a meaningful relationship between earnings management and operating cash flows management. In other words, earnings management creates and shapes operating cash flows management. In addition, after controlling for the loss reporting, firm size and firm's financial risk, the results indicate that there was a relationship between loss reporting and firm size with the cash flows management. When firms report loss, then operating cash flows increases. Finally, operating cash flows decreases when firm size increases. However, the study did not provide any evidence to believe there was any relationship between financial risk and cash flows management.

\section{The proposed model}

This study presents an empirical investigation to measure the relationship between traditional accounting performance measurement as well as theory of constraint-based figures with operating cash flow. Traditional accounting measurement includes net profit and return of investment (ROI) and theory of constraint method includes net profit and return of investment based on theory of constraints (ROIT). The study selects 69 firms list on Tehran Stock Exchange over the period 20002010 based on the following criteria,

1. All firms must have the same fiscal years ending official calendar year in Iran.

2. All firms must be listed on Tehran Stock Exchange before year 2000 .

3. Only manufacturing firms were considered for this study.

4. There must be no change on their fiscal calendar during the time of study.

The study selected 759 year-firm observation from 15 different manufacturing industries. In our survey, net operating profit is calculated as the difference between the cost of product and operating expenses. In addition, return of investment is calculated as a ratio of operating profit divided by average total assets. In order to calculate net profit based on accounting performance (NPT), first throughput must be calculated. In theory of constraints, this measure is calculated as a difference between total revenue and total variable costs (TVC). Then, we subtract operating expenses from throughput to reach NPT. Next, we calculated ROIT as follows,

$R O I T=(T-O E) / I=N P / I$

where I is the average inventory.

Table 1 summarizes some basic statistics including operating cash flow (OCF), net operating profit (NP), net operating profit based on theory of constraints (NPT), return of investment based on traditional system, return of investment based on theory of constraints (ROIT) and size of firms associated with the proposed study of this paper. 
Table 1

The summary of basic statistics

\begin{tabular}{lccccccc}
\hline Variable & Observation & Mean & Standard dev. & $\min$ & $\max$ & Skewness & Kurtosis \\
\hline OCF & 758 & 0.1902 & 0.1952 & -0.7340 & 0.9419 & 0.353 & 4.849 \\
NP & 757 & 0.2423 & 0.1665 & -0.2941 & 1.0997 & 1.105 & 5.344 \\
NPT & 756 & 0.2425 & 0.1761 & -0.5007 & 0.8808 & 0.073 & 4.120 \\
ROI & 755 & 0.9016 & 3.058 & -14.941 & 36.084 & 6.067 & 64.185 \\
ROIT & 752 & 1.1120 & 3.764 & -13.868 & 70.206 & 9.974 & 163.46 \\
SIZE & 759 & 12.933 & 1.467 & 9.797 & 18.321 & 0.859 & 4.324 \\
\hline
\end{tabular}

In our study, the average operating cash flow is equal to 0.19 , which means cash flow is accounted for $19 \%$ of total firms' sales. In addition, the ROIT was $24.25 \%$ and there was a decline trend on ROI from $27 \%$ in year 2000 to $19 \%$ in year 2010 . We have measured Pearson correlation ratios among the research variables and Table 2 summarizes the results of our survey.

Table 2

The summary of Pearson correlation ratio

\begin{tabular}{|c|c|c|c|c|c|c|}
\hline & $\mathrm{OCF}$ & NP & NPT & ROI & ROIT & SIZE \\
\hline $\mathrm{OCF}$ & 1 & & & & & \\
\hline \multicolumn{7}{|l|}{ P-Value } \\
\hline NP & 0.597 & 1 & & & & \\
\hline P-Value & $(0.000)$ & & & & & \\
\hline NPT & 0.502 & 0.715 & 1 & & & \\
\hline P-Value & $(0.000)$ & $(0.000)$ & & & & \\
\hline ROI & 0.070 & 0.170 & 0.087 & 1 & & \\
\hline P-Value & $(0.053)$ & $(0.000)$ & $(0.017)$ & & & \\
\hline ROIT & 0.011 & 0.053 & 0.102 & 0.761 & 1 & \\
\hline P-Value & $(0.761)$ & $(0.141)$ & $(0.005)$ & $(0.000)$ & & \\
\hline SIZE & 0.085 & 0.097 & 0.090 & -0.028 & 0.107 & 1 \\
\hline P-Value & $(0.019)$ & $(0.007)$ & $(0.013)$ & $(0.440)$ & $(0.003)$ & \\
\hline
\end{tabular}

As we can observe from the results of Table 2, there is a positive and meaningful relationship between net profit (NP) and operating cash flow (OCF), between net profit in theory of constraint (NPT) and OCF and between ROIT and ROI. The proposed study of this paper considers the following two hypotheses. The first hypothesis of the survey considers the relationship between traditional performance measurement and OCF, which consists of the following three sub-hypotheses,

The first sub-hypothesis of this survey examines the relationship between NP and OCF as follows,

$$
\begin{cases}H_{0}: & \text { There is no relationship between NP and OCF } \\ H_{1}: & \text { There is a relationship between NP and OCF }\end{cases}
$$

The second sub-hypothesis of this survey examines the relationship between ROI and OCF as follows,

$\begin{cases}H_{0}: & \text { There is no relationship between ROI and OCF } \\ H_{1}: & \text { There is a relationship between ROI and OCF }\end{cases}$

The second hypothesis of the survey considers the relationship between theory of constraints based performance measurement and OCF, which consists of the following two sub-hypotheses.

The first sub-hypothesis of this survey examines the relationship between NP and OCF as follows, 
$\left\{H_{0}:\right.$ There is no relationship between NPT and OCF

$H_{1}$ : There is a relationship between NPT and OCF

The second sub-hypothesis of this survey examines the relationship between ROIT and OCF as follows,

$\begin{cases}H_{0}: & \text { There is no relationship between ROIT and OCF } \\ H_{1}: & \text { There is a relationship between ROIT and OCF }\end{cases}$

The proposed study of this paper uses regression analysis to verify these hypotheses and the results are presented next.

Finally, the third hypothesis of this paper investigates whether TOC based method is capable of providing better results than traditional method. In other word, this hypothesis examines whether there is a meaningful difference between the results of two methods in terms of describing performance measurement.

\section{The results}

\subsection{The first hypothesis: The relationship between traditional performance measurement and OCF}

In order to examine the first hypothesis, we apply the following regression model,

$O C F_{i, t}=\alpha_{i, t}+\beta_{1} N P_{i, t}+\beta_{2} R O I_{i, t}+\beta_{3} S I Z E_{i, t}+\varepsilon_{i, t}$,

where SIZE represents the size of the firm. Based on Chaw and Housman tests, we have decided to choose panel data method with fixed method and the results of stepwise regression analysis is as follows,

$O C F_{i, t}=0.2629+0.3324 N P_{i, t}$,

Table 3 summarizes the results of testing the first hypothesis of this survey.

Table 3

The summary of testing the first hypothesis of the survey

\begin{tabular}{lllll}
\hline Variable & Coefficient & t-value & Sig. & Results \\
\hline NP & 0.3324 & 7.350 & 0.0000 & Confirmed \\
ROI & -0.0008 & -0.535 & 0.5928 & Reject \\
\hline $\mathrm{R}^{2}=0.6605$ & & & &
\end{tabular}

As we can observe from the results of Table 3, the relationship between NP and OCF is confirmed when the level of significance is five percent but the relationship between ROI and OCF is not confirmed.

\subsection{The $2^{\text {nd }}$ hypothesis: The relationship between TOC based performance measurement and OCF}

In order to examine the second hypothesis, we apply the following regression model,

$$
O C F_{i, t}=\alpha_{i, t}+\beta_{1} N P T_{i, t}+\beta_{2} R O I T_{i, t}+\beta_{3} S I Z E_{i, t}+\varepsilon_{i, t},
$$


where SIZE represents the size of the firm. Based on Chaw and Housman tests, we have decided to choose panel data method with fixed method and the results of stepwise regression analysis is as follows,

$$
O C F_{i, t}=0.4670+0.2290 N P T_{i, t}-0.0256 S I Z E_{i, t},
$$

Table 4 summarizes the results of testing the second hypothesis of this survey.

\section{Table 4}

The summary of testing the second hypothesis of the survey

\begin{tabular}{lllll}
\hline Variable & Coefficient & t-value & Sig. & Results \\
\hline NPT & 0.2290 & 6.098 & 0.0000 & Confirmed \\
ROIT & 0.0001 & 0.108 & 0.9137 & Reject \\
\hline $\mathrm{R}^{2}=0.6227$ & & & &
\end{tabular}

As we can observe from the results of Table 4, the relationship between NPT and OCF is confirmed when the level of significance is five percent but the relationship between ROIT and OCF is not confirmed.

\subsection{The third hypothesis: Traditional method versus TOC method}

The last hypothesis of this survey investigates whether there is a meaningful difference between two methods of traditional and TOC method. Table 5 summarizes the results of our survey using Wong $\mathrm{Z}$ test.

\section{Table 5}

The summary of testing the third hypothesis

\begin{tabular}{lllll}
\hline Model & $\mathrm{R}^{2}$ & Wong & P-value & Result \\
\hline First model & 0.6605 & -13.8271 & 0.000 & Confirmed \\
Second model & 0.6227 & & & \\
\hline
\end{tabular}

According the results of Table 5, we can conclude that there is a difference between two methods on measuring the performance of the manufacturing firms. In addition, it seems that TOC based method has better capability to measure the performance of the firms.

\section{Discussion and conclusion}

In this paper, we have presented a survey on relationship between the performances of manufacturing firms measured by traditional as well as theory of constraints methods and operating cash flow. The proposed study uses eleven years of information on some listed firms on Tehran Stock Exchange and using Pearson correlation ratio as well as regression analysis has determined that TOC method is better method for measuring the performance of listed firms compared with traditional one.

\section{Acknowledgment}

The authors would like to thank the anonymous referees for constructive comments on earlier version of this paper. 


\section{References}

Banimahd, B \& Aliabadi, M. (2013). A study on relationship between earnings management and operating cash flows management: Evidence from Tehran Stock Exchange. Management Science Letters, 3(6), 1677-1682.

Boyd, L. H., \& Cox Iii, J. F. (2002). Optimal decision making using cost accounting information. International Journal of Production Research, 40(8), 1879-1898.

Campbell, R. J. (1995). Steeling Time with ABC or TOC. Management Accounting-New York, 76, 31-31.

Carnevale, A. P., \& Schulz, E. R. (1990). Return on Investment: Accounting for Training. Training and Development journal, 44(7), S1-S32.

Chakraborty, P. S., Majurnder, G., \& Sarkar, B. (2006). Constraint resource management and production related decision- a case study. Journal of the Institution of Engineers(India) Part PR, Production Engineering Division, 86, 48-53.

France, A. (2010). Management accounting practices reflected in job advertisements. Journal of New Business Ideas \& Trends, 8(2), 41-57.

Goldratt, E. M. (1990). Theory of constraints. North River.

Gupta, M., Baxendale, S. J., \& McNamara, K. (1997). Integrating TOC and ABCM in a health care company. Journal of Cost Management, 11(4), 23-33.

Kaplan, S. N., \& Zingales, L. (1997). Do investment-cash flow sensitivities provide useful measures of financing constraints?. The Quarterly Journal of Economics, 112(1), 169-215.

Lockamy III, A. (2003). A constraint-based framework for strategic cost management. Industrial Management \& Data Systems, 103(8), 591-599.

Noreen, E. W., Smith, D., \& Mackey, J. T. (1995). The theory of constraints and its implications for management accounting (Vol. 1, p. 995). Great Barrington, MA: North River Press.

Said, A. A., HassabElnaby, H. R., \& Nowlin, T. S. (2008). The relative and incremental information content of earnings vs cash recovery rates. Review of Accounting and Finance, 7(4), 372-395. 